\title{
Preliminary Evaluation of the Genetic Relatedness of Three Species of the Subgenus Dendromyia Theobald and Other Species of the Genus Wyeomyia Theobald (Diptera: Culicidae)
}

\author{
Monique Albuquerque Motta/ ${ }^{+}$, Ricardo Lourenço-de-Oliveira, Fernando \\ Araujo Monteiro*, Luciana Ramos Barros
}

\begin{abstract}
Departamento de Entomologia, Instituto Oswaldo Cruz, Av. Brasil 4365, 21045-900 Rio de Janeiro, RJ, Brasil *Departamento de Genética, Universidade Federal do Rio de Janeiro, Av. Brigadeiro Trompowsky, 21941-590

Rio de Janeiro, RJ, Brasil
\end{abstract}

An eletrophoretic analysis of three species of the subgenus Dendromyia (Wyeomyia luteoventralis, $\mathrm{Wy}$. ypsipola and $\mathrm{Wy}$. testei) and three species belonging to different groups in the genus Wyeomyia (Wy. negrensis, Wy. mystes and Wy.confusa) was performed. Eight enzyme loci were analyzed. High values of genetic identity were detected among the species of the subgenus Dendromyia: Wy. luteoventralis, Wy. ypsipola and Wy. testei (mean value 0.63). On the other hand low values of genetic identity were observed among $\mathrm{Wy}$. negrensis, $\mathrm{Wy}$. mystes and Wy. confusa (mean value 0.23), suggesting that they belong, at least, to distinct subgenera within the Genus Wyeomyia. The UPGMA phenogram revealed the grouping of the Dendromyia species, while the others clustered at lower identity levels.

Key words: mosquitoes - Wyeomyia - Dendromyia - allozyme - genetic identity

Most Neotropical Sabethini belong to the genus Wyeomyia Theobald. These diurnal sylvatic mosquitoes may be vectors of arboviruses in the Neotropical region (Hervé et al. 1986). The subgenus Dendromyia Theobald holds most species in the genus Wyeomyia. The subgenus Dendromyia was previously considered to be composed of 43 species, the majority of which were superficially described from only a few specimens. In general, the immature stages and the morphological characters of males and females of Dendromyia species are poorly known or are unknown. Therefore the phylogenetic relationships among species in the subgenus Dendromyia remain obscure.

Currently, six nominal species are recognized as belonging to the subgenus Dendromyia: Wy. luteoventralis Theobald (the type-species of Dendromyia), Wy. ypsipola Dyar, Wy. jocosa Dyar \& Knab, Wy. testei Senevet \& Abonnenc, Wy. trifurcata Clastrier and Wy. complosa Dyar (Motta \& Lourenço-de-Oliveira 1995). An extensive morphological analysis and redescription of immature stages as well as both males and females of these six species (unpublished data) showed that they share more characters than the group of six spe-

${ }^{+}$Corresponding author. Fax: + 55-21-290.9339

Received 11 June 1997

Accepted 23 January 1998 cies shares with other Wyeomyia species. The purpose of this study is to perform a comparative allozyme analysis and to estimate genetic similarities among these species and other related Wyeomyia species. The level of genetic similarity is expressed by identity values (I) (Nei 1972), and can be used to determine taxonomic relationships. The technique of allozyme eletrophoresis has been successfully and widely used to assist in resolving taxonomic problems and to infer on genetic relationships (Bullini 1982, Thorpe \& Solé-Cava 1994). In the present report we compare six species, three from the subgenus Dendromyia and three other species previously included in different groups or series in the subgenus Dendromyia, as proposed by Lane and Cerqueira (1942).

\section{MATERIALS AND METHODS}

Multilocus enzyme eletrophoresis was carried out in agarose gels with adult specimens, as described by Momen and Salles (1985) with the modifications of Rosa-Freitas (1988).

The allozyme study compared three species of Dendromyia (Wy. luteoventralis, Wy. ypsipola and Wy. testei) and three species belonging to the following groups or "series" (Lane \& Cerqueira 1942): series Prosopolepis (Wy. confusa Lutz), series Cleobonnea (Wy. negrensis Gordon \& Evans) and series Dendromyia (Wy. mystes Dyar).

The allozyme analysis included field collected larvae and adults (on human bait), in the follow- 
ing localities in Brazil: Porto Velho, State of Rondônia; Manaus, State of Amazonas; Belém, State of Pará; Peixoto de Azevedo, State of Mato Grosso; Itaguaí, Nova Friburgo and Guapimirim, State of Rio de Janeiro; São Paulo, State of São Paulo, and Joinville, State of Santa Catarina. The number of individuals analyzed varied according to species and locality (Table I).

Twenty-six enzymes were tested in different buffer systems: citric buffer (ODH, ALDH, ADH, ACP, LEDH, LDH, ACON, GDH, MPI, G6PDH, PEP, PEPD, a EST, NH and HK); maleic buffer (ADH, MPI, G6PDH, PEP1, HK and HBDH); and phosphate buffer (LEDH, MPI, G6PDH, PEP2, $\mathrm{NH}, \mathrm{GOT}$ and HBDH). Only seven of the enzymes were scorable, by producing sharp, defined bands comprising a total of eight enzymatic loci. Enzymes and buffer systems used were: (1) tris - maleic buffer $0.1 \mathrm{M}$ (pH 7.4): malic enzyme 1.1.1.40 (ME), isocitrate dehydrogenase 1.1.1.42 (IDH) and phosphoglucomutase 2.7.5.1. (PGM); (2) phosphate buffer $0.2 \mathrm{M}$ (pH 8.0): malate dehydrogenase 1.1.1.37 (MDH), glucose phosphate isomerase 5.3.1.9 (GPI) and fumarate hydratase 4.2.1.2 (FUM) and (3) tris citric 0.2 M (pH 8.1): 6phosphogluconate dehydrogenase 1.1.1.44 (6 PGDH).

Allozyme data were analysed using the genetic computer program BIOSYS - 1 (Swofford \& Selander 1981). Levels of heterozygosity and genetic distances and identities (Nei 1978) were estimated for all species analyzed. The genetic identities were then used to build a phenogram using the unweighted pair group mean analysis (UPGMA) (Sneath \& Sokal 1973).

\section{RESULTS}

One out of the eight loci analyzed - GPI - was monomorphic in all species. FUM was monomorphic in five species except in Wy. confusa, while PGM was polymorphic in all species (Table I).

Enzymes that presented polymorphic loci were: in Wy. testei (PGM, IDH 1 and 2, ME and 6PGDH), Wy. negrensis (MDH, PGM, IDH 1 and 2 and ME) and Wy. mystes (MDH, PGM, IDH 2, ME and 6 PGDH). The frequency of polymorphic loci was $62 \%$ for these three species; the mean heterozygosity values were $0.13,0.08$ and 0.13 , and mean number of alleles per locus were 2.3, 1.9 and 2.3, respectively (Table II).

Except for GPI, the majority of enzymes was polymorphic $(87.5 \%)$ in Wy. confusa, with mean heterozygosity of 0.082 and a mean number of 2.6 alleles per locus. In Wy. luteoventralis six loci were polymorphic (MDH, PGM, IDH 1 and 2, ME and $6 \mathrm{PGDH})$ and the percentage of polymorphic loci was $75 \%$, with the mean number of 2.0 alleles per locus and the observed mean heterozigozity of 0.23 , which was the highest among the analyzed species. Wy. ypsipola presented only one polymorphic locus (PGM), and the values were 12.5, 0.042 and 1.3 respectively (Table II).

Values of genetic identities (I) and distances (D) (Nei 1978) between the species are listed in Table III. High values of genetic identity were detected among the Dendromyia species - Wy. testei, Wy. luteoventralis and Wy. ypsipola (mean value $0.63)$. On the other hand, low I values were observed among Wy. negrensis, Wy. mystes and Wy. confusa (mean value 0.23). The UPGMA phenogram constructed with identity values demonstrated a grouping of Wy. luteoventralis, Wy. ypsipola and Wy. testei, while other species clustered at lower identity levels.

\section{DISCUSSION}

This is the first allozyme analysis performed with Neotropical species of Wyeomyia. In the course of this study, we found that several enzyme systems used in similar analyses of other culicid mosquitoes (Anopheles, Rosa-Freitas et al. 1990, Narang et al. 1991; Culex, Humeres et al. 1990; Aedes, Nielsen et al. 1995) did not produce readable bands.

The limited number of enzymatic loci analyzed may not provide the best estimate of variation that actually exists between the assayed species. Regardless, the results of the allozyme analysis still agreed with the morphological studies and the subsequent taxonomic treatment by Motta and Lourenço-de-Oliveira (1995) for species belonging to the subgenus Dendromyia.

The highest percentage of polymorphic loci (Table II) was observed in Wy. confusa (87.5\%). The percentage of polymorphic loci in this species is higher than those found in some mosquitoes, such as An. albimanus (55\%, according to Narang et al. 1991), An. aquasalis (27\%, Flores-Mendoza 1994) and An. pseudopunctipennis (ranging from $12.1 \%$ to $78.8 \%$, Manguin et al. 1995). Alternatively, Wy. ypsipola presented a low percentage of polymorphic loci (12.5\%).

The mean heterozygosity values found for the analyzed Wyeomyia species are within the range observed for other mosquito groups, such as Anopheles (Narang et al. 1991, Flores-Mendoza 1994).

Among the species currently included in the subgenus Dendromyia (Wy. luteoventralis, Wy. ypsipola and Wy. testei), high values of genetic identity were obtained (Table III). This reinforces the conclusion from morphological analysis, that these three species comprise a distinct group within the genus Wyeomyia. In addition, the highest I value 
TABLE I

Allele frequencies for polymorphic enzyme loci in Wyeomyia negrensis, Wy. mystes, Wy. confusa, Wy. luteoventralis, Wy. ypsipola and Wy. testei. Number of specimens tested in parenthesis

\begin{tabular}{|c|c|c|c|c|c|c|}
\hline \multirow[b]{2}{*}{ Locus } & \multicolumn{6}{|c|}{ Species and populations } \\
\hline & $\begin{array}{l}\text { Wy. negrensis } \\
\text { Manaus (14) } \\
\text { Peixoto de } \\
\text { Azevedo (27) } \\
\text { Belém (6) }\end{array}$ & $\begin{array}{l}\text { Wy. mystes } \\
\text { Itaguaí (39) }\end{array}$ & $\begin{array}{l}\text { Wy. confusa } \\
\text { São Paulo (2) } \\
\text { Nova Friburgo (7) } \\
\text { Guapimirim (14) } \\
\text { Joinville (17) }\end{array}$ & $\begin{array}{l}\text { Wy. luteoventralis } \\
\text { Belém (6) }\end{array}$ & $\begin{array}{l}\text { Wy. ypsipola } \\
\text { Belém (2) } \\
\text { Porto Velho (4) } \\
\text { Peixoto de } \\
\text { Azevedo (3) }\end{array}$ & $\begin{array}{l}\text { Wy. testei } \\
\text { Porto Velho (38) }\end{array}$ \\
\hline MDH & (39) & (39) & (37) & (3) & (9) & (37) \\
\hline A & .013 & .000 & .000 & .000 & .000 & .000 \\
\hline B & .987 & .064 & .014 & .500 & .000 & .000 \\
\hline $\mathrm{C}$ & .000 & .000 & .986 & .000 & .000 & .000 \\
\hline D & .000 & .936 & .000 & .500 & 1.000 & 1.000 \\
\hline PGM & (32) & (30) & (25) & (5) & (9) & (32) \\
\hline A & .000 & .000 & .020 & .000 & .000 & .188 \\
\hline B & .000 & .000 & .000 & .000 & .000 & .203 \\
\hline $\mathrm{C}$ & .891 & .000 & .040 & .000 & .000 & .000 \\
\hline $\mathrm{D}$ & .000 & .000 & .140 & .100 & .111 & .531 \\
\hline E & .078 & .000 & .780 & .600 & .389 & .016 \\
\hline $\mathrm{F}$ & .031 & .900 & .000 & .000 & .500 & .016 \\
\hline G & .000 & .050 & .020 & .300 & .000 & .047 \\
\hline $\mathrm{H}$ & .000 & .050 & .000 & .000 & .000 & .000 \\
\hline IDH1 & (41) & (26) & (39) & (5) & (9) & $(38)$ \\
\hline A & .000 & 1.000 & .000 & .000 & .000 & .013 \\
\hline B & . 122 & .000 & .013 & .300 & .000 & .000 \\
\hline C & .000 & .000 & .987 & .700 & 1.000 & .974 \\
\hline D & .854 & .000 & .000 & .000 & .000 & .013 \\
\hline E & .024 & .000 & .000 & .000 & .000 & .000 \\
\hline IDH2 & (40) & (39) & (39) & (5) & (9) & (35) \\
\hline A & .313 & .000 & .026 & .400 & 1.000 & .000 \\
\hline B & .688 & .526 & .962 & .400 & .000 & .000 \\
\hline C & .000 & .462 & .013 & .000 & .000 & .029 \\
\hline D & .000 & .000 & .000 & .200 & .000 & .971 \\
\hline E & .000 & .013 & .000 & .000 & .000 & .000 \\
\hline ME & (37) & (39) & (30) & (6) & (9) & (34) \\
\hline A & .081 & .000 & .000 & .000 & .000 & .000 \\
\hline B & .000 & .000 & .033 & .000 & .000 & .000 \\
\hline C & .919 & .013 & .000 & .833 & .000 & .206 \\
\hline D & .000 & .013 & .000 & 167 & 1.000 & .794 \\
\hline E & .000 & .026 & .967 & .000 & .000 & .000 \\
\hline F & .000 & .949 & .000 & .000 & .000 & .000 \\
\hline FUM & (31) & (32) & (30) & (2) & (9) & (30) \\
\hline A & .000 & 1.000 & .000 & .000 & .000 & .000 \\
\hline B & .000 & .000 & .100 & 1.000 & 1.000 & 1.000 \\
\hline C & .000 & .000 & .900 & .000 & .000 & .000 \\
\hline D & 1.000 & .000 & .000 & .000 & .000 & .000 \\
\hline GPI & (31) & (31) & (30) & (6) & (9) & (28) \\
\hline A & .000 & .000 & .000 & .000 & .000 & 1.000 \\
\hline B & 1.000 & 1.000 & 1.000 & 1.000 & 1.000 & .000 \\
\hline 6PGD & (31) & (30) & (26) & (4) & (9) & (25) \\
\hline A & .000 & .000 & .058 & .000 & .000 & .000 \\
\hline B & .000 & .000 & .904 & .500 & .000 & .940 \\
\hline $\mathrm{C}$ & 1.000 & .017 & .000 & .000 & .000 & .000 \\
\hline D & .000 & .917 & .019 & .500 & 1.000 & .060 \\
\hline E & .000 & .067 & .019 & .000 & .000 & .000 \\
\hline
\end{tabular}




\section{TABLE II}

Measures of genetic variation of Wyeomyia negrensis, Wy. mystes, Wy. confusa, Wy. luteoventralis, Wy. ypsipola and Wy. testei

\begin{tabular}{|c|c|c|c|c|c|}
\hline \multirow[t]{2}{*}{ Species } & \multirow{2}{*}{$\begin{array}{l}\text { Mean sample } \\
\text { size per locus }\end{array}$} & \multirow{2}{*}{$\begin{array}{c}\text { Mean No. of } \\
\text { alleles per } \\
\text { locus }\end{array}$} & \multirow{2}{*}{$\begin{array}{c}\text { Percentage } \\
\text { of loci } \\
\text { polymorphic }^{a}\end{array}$} & \multicolumn{2}{|c|}{ Mean heterozygosity } \\
\hline & & & & Direct-count & $\begin{array}{l}\text { HdyWbg } \\
\text { expected }\end{array}$ \\
\hline \multirow[t]{2}{*}{ Wy. negrensis } & 35.3 & 1.9 & \multirow[t]{2}{*}{62.5} & .081 & .134 \\
\hline & (1.6) & $(.3)$ & & $(.045)$ & $(.056)$ \\
\hline \multirow[t]{2}{*}{ Wy. mystes } & 33.3 & 2.3 & \multirow[t]{2}{*}{62.5} & .127 & .136 \\
\hline & $(1.8)$ & $(.4)$ & & $(.057)$ & $(.061)$ \\
\hline \multirow[t]{2}{*}{ Wy. confusa } & 32.0 & 2.6 & \multirow[t]{2}{*}{87.5} & .082 & .117 \\
\hline & $(2.0)$ & $(.5)$ & & $(.027)$ & $(.044)$ \\
\hline \multirow[t]{2}{*}{ Wy. luteoventralis } & 4.5 & 2.0 & \multirow[t]{2}{*}{75.0} & .233 & .407 \\
\hline & $(.5)$ & $(.3)$ & & $(.079)$ & $(.098)$ \\
\hline \multirow[t]{2}{*}{ Wy. ypsipola } & 9.0 & 1.3 & \multirow[t]{2}{*}{12.5} & .042 & .078 \\
\hline & $(.0)$ & $(.3)$ & & $(.042)$ & $(.078)$ \\
\hline \multirow[t]{2}{*}{ Wy. testei } & 32.4 & 2.3 & \multirow[t]{2}{*}{62.5} & .133 & .151 \\
\hline & $(1.6)$ & $(.6)$ & & $(.074)$ & $(.081)$ \\
\hline
\end{tabular}

$a$ : a locus is considered polymorphic if more than one allele was detected; ${ }^{b}$ : unbiased estimate (see Nei 1978).

\section{TABLE III}

Estimates of Nei's (1978) unbiased genetic identity (above diagonal) and genetic distance (below diagonal) for Wyeomyia negrensis, Wy. mystes, Wy. confusa, Wy. luteoventralis, Wy. ypsipola and Wy. testei

\begin{tabular}{lrrrrrr}
\hline Species & 1 & 2 & 3 & 4 & 5 & 6 \\
\hline 1 Wy. negrensis & $* * * * *$ & .214 & .255 & .478 & .190 & .029 \\
2 Wy. mystes & 1.542 & $* * * * *$ & .223 & .383 & .464 & .153 \\
3 Wy. confusa & 1.368 & 1.502 & $* * * * *$ & .543 & .339 & .289 \\
4 Wy. luteoventralis & .738 & .959 & .610 & $* * * * *$ & .762 & .573 \\
5 Wy. ypsipola & 1.661 & .768 & 1.080 & .272 & $* * * *$ & .551 \\
6 Wy. testei & 3.525 & 1.880 & 1.241 & .556 & .596 & $* * * * *$ \\
\hline
\end{tabular}

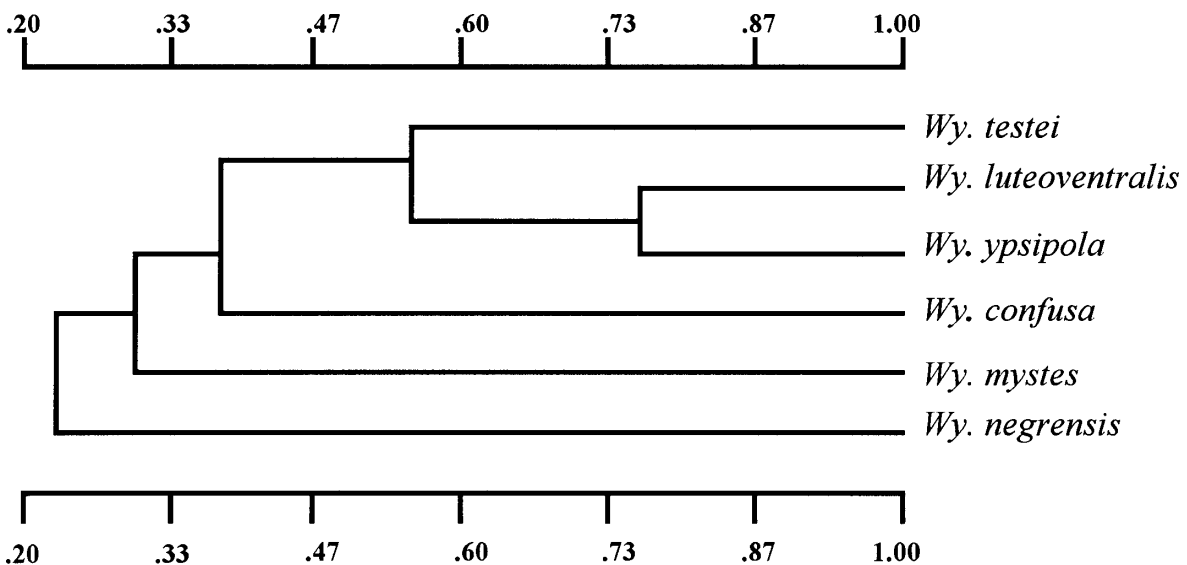

Phenogram of genetic relationships among Wyeomyia negrensis, Wy. mystes, Wy. confusa, Wy. luteoventralis, Wy. ypsipola and Wy. testei, using unweighted pair-group (with arithmetic mean) clustering of Nei (1978) identities. 
was obtained between Wy. luteoventralis and Wy. ypsipola $(\mathbf{I}=0.76)$. In spite of $W y$. luteoventralis and Wy. ypsipola having very distinct external male and female characters, the morphological characters of the immature stages are nearly identical.

On the other hand, the allozyme analyses of Wy. negrensis, Wy. mystes, Wy. confusa (belonging to taxonomically undetermined subgenera) and the above mentioned members of the subgenus Dendromyia (Wy. luteoventralis, Wy. ypsipola and Wy. testei) showed low genetic identity among them, with I values ranging from 0.03 to 0.54 . This also agrees with the current taxonomic treatment of the genus Wyeomyia based on morphological analysis by Motta and Lourenço-de-Oliveira (1995) and Motta (1996). The highest I value found between a member of the subgenus Dendromyia and a non Dendromyia species was that between $W y$. luteoventralis and Wy. confusa (0.54). Indeed, Wy. confusa is bionomically similar to the Dendromyia species, e.g. predatory behavior of larvae and use of Callathea and Heliconia plants as larval habitats. Regardless, Wy. confusa belongs to the Prosopolepis group of Wyeomyia because it is neither morphologically related nor has enough genetic similarity with other members of the subgenus Dendromyia.

In reviews on the relationship of $\mathbf{I}$ to systematic diversity of vertebrates, invertebrates and plants, Thorpe (1982) and Thorpe and Solé-Cava (1994) concluded that generally conspecific populations have I values above 0.85 , while between congeneric species the usual range is about 0.85 to 0.30 and between genera $\mathbf{I}$ values are usually in the range from 0.45 to zero (generally bellow 0.35 ). The I values observed among Wy. luteoventralis, Wy. ypsipola and Wy. testei, ranging from 0.55 to 0.76 , show that they are closely related species and reinforce their congeneric relationship. On the other hand, the allozyme analysis of Wy. negrensis, Wy. mystes and Wy. confusa presented low genetic identity with $\mathbf{I}$ values ranging from 0.21 to 0.26 , suggesting that they belong to distinct groups, probably different subgenera within the genus Wyeomyia. Nevertheless, the I values between some of them were very low, such as between $W y$. testei and Wy. negrensis $(\mathbf{I}=0.03)$. These results suggest that they may belong to different genera. Indeed, Wy. negrensis, Wy. confusa and Wy. mystes were previously thought to belong to the series Cleobonnea, Prosopolepis and Dendromyia respectively (Table III). Our findings suggest that these three series consisted of an unnatural classification, and that more detailed and comprehensive morphological and genetic studies should be conducted to better understand the phylogenetic relationships among the Wyeomyia species.

\section{ACKNOWLEDGEMENTS}

To Dr MG Rosa-Freitas and M Monteiro for suggestions in the manuscript; Drs H Momen, R Pacheco and NA Honório for the sugestions and support in the laboratory; Dr AT Rosa and OV Silva, Evandro Chagas Institute, for the support on the field.

\section{REFERENCES}

Bullini L 1982. Enzyme variants in the identification of parasites and vectors: methodological aspects of the electrophoretic approach, p. 53-69. In BN Newton, F Michal (eds), New Aproaches to the Identification of Parasites and Their Vectors, WHO, Basel, Switzerland.

Flores-Mendoza CF 1994. Um Estudo Sobre Alguns Aspectos Comportamentais, Morfológicos e Bioquímicos de Anopheles aquasalis Curry, 1932, MSc Thesis, Instituto Oswaldo Cruz, Rio de Janeiro, $172 \mathrm{pp}$.

Hervé JP, Dégallier N, Travassos da Rosa APA, Pinheiro FP, Sá Filho GC 1986. Arboviroses - Aspectos ecológicos, p. 409-437. In Instituto Evandro Chagas - 50 Anos de Contribuição às Ciências Biológicas e à Medicina Tropical, Vol I., Fund Serv Saúde Pública, Belém.

Humeres SG, Gardenal CN, Almirón W, Sereno R, Sabattini MS 1990. Culex species (Diptera: Culicidae) from Central Argentina identification by electrophoretic zymograms and genetic relationships. $J$ Med Entomol 27: 784-788.

Lane J, Cerqueira NL 1942. Os sabetíneos da América (Diptera, Culicidae). Arch Zool S Paulo 3: 473-849.

Manguin S, Roberts DR, Peyton EL, Fernandez-Salas I, Barreto M, Loayza RF, Spinola RE, Granaou RM, Rodriguez MH 1995. Biochemical systematics and population genetic structure of Anopheles pseudopunctipennis, vector of malaria in Central and South America. Am J Trop Med Hyg 53: 362-377.

Momen H, Salles CA 1985. Enzyme markers for Vibrio cholerae: identification of classical, eltor and environmental strains. Trans $R$ Soc Trop Med Hyg 79: 773-776.

Motta MA 1996. O Subgênero Dendromyia Theobald (DIPTERA: CULICIDAE): Um Estudo Morfológico e Bioquímico, MSc Thesis, Instituto Oswaldo Cruz, Rio de Janeiro, $121 \mathrm{pp}$.

Motta MA, Lourenço-de-Oliveira R 1995. Wyeomyia luteoventralis Theobald, the type species of the subgenus Dendromyia Theobald (Diptera: Culicidae). Mem Inst Oswaldo Cruz 90: 375-385.

Narang SK, Seawright JA, Suarez MF 1991. Genetic structure of natural populations of Anopheles albimanus in Colombia. J Am Mosq Control Assoc 7: 437-445.

Nei M 1972. Genetic distance between populations. Amer Natur 106: 283-292.

Nei M 1978. Estimation of average heterozygosity and genetic distance from a small number of individuals. Gen 89: 583-590.

Nielsen BO, Loeschcke V, Simonsen V 1995. Separating female Aedes cantans and Aedes annulipes by 
194 Genetic Relatedness of Dendromyia Species - Monique A Motta et al.

morphology and allozymes (Diptera: Culicidae). Mosq Syst 27: 100-109.

Rosa-Freitas MG 1988. Anopheles albitarsis LynchArribálzaga, 1878 (Diptera; Culicidae): Um Estudo Comparativo de Caracteres Morfológicos, Bioquímicos e Comportamentais de Populações de Dez Localidades, MSc Thesis, Instituto Oswaldo Cruz, Rio de Janeiro, 105 pp.

Rosa-Freitas MG, Deane LM, Momen H 1990. A morphological, isoenzymatic and behavioural study of ten populations of Anopheles (Nyssorhynchus) albitarsis Lynch-Arribalzaga, 1878 including from the type-locality, Baradero, Argentina. Mem Inst
Oswaldo Cruz 85: 275-289.

Swofford DL, Selander RB 1981. BIOSYS-1: A FORTRAN program for the comprehensive analysis of eletrophoretic data in population genetics and systematics. J Hered 72: 281-283.

Sneath PHA, Sokal RR 1973. Numerical Taxonomy, Freeman, San Francisco, 573 pp.

Thorpe JP 1982. The molecular clock hypothesis: biochemical evolution, genetic differentiation and systematics. Annu Rev Ecol Syst 13: 139-168.

Thorpe JP, Solé-Cava AM 1994. The use of allozyme electrophoresis in invertebrate systematics. Zool Scr 23: 3-18. 